\title{
DEVELOPMENT STRATEGY TOURISM TIKUS ISLAND BENGKULU PROVINCE WITH SWOT ANALYSIS
}

\author{
Herlin ${ }^{1 *}$ and Rina Trisna Yati ${ }^{2}$ \\ ${ }^{1,2}$ Universitas Dehasen, Bengkulu, Indonesia
}

\begin{abstract}
The purpose of this study was to find out how the strategy of developing Tikus island of Bengkulu province tourism. This type of research is a descriptive exploratory study, using primary (observation and questionnaire) and secondary data obtained by the Bengkulu Province Tourism Office, with samples in this study totaling 125 people. Methods of data analysis using SWOT Analysis.

Based on the results of the SWOT analysis (Strenghts, Weakness, Opportunity and Treaths) showed that the strategy of developing Tikus Island Bengkulu province consisting of internal strategic factors (IFAS) consisting of Strength (S) and Weakness (W) obtained a total score of 4.28, this means that the attraction Tikus Island Bengkulu province has a strength that is greater than weakness. Whereas external factors (EFAS), which consist of opportunities and Threats $(T)$ with a total score of 4.25 and opportunities $(O)$ of 2.32, which means that the attraction Tikus Island Bengkulu province has a greater opportunity from threats. The meeting point between strengths, weaknesses, opportunities and threats is in quadrant I, which means that the strategy implemented is to support aggressive strategy. In this quadrant I shows that attractions Tikus Island Bengkulu province have equal opportunities and Weakness (W) so that the strategy that can be applied is to support aggressive policies (Growth Oriented Strategy, namely by developing transportation and supporting facilities to the region). Keywords: Development strategy tourism, Tikus Island, SWOT analysiys
\end{abstract}

\section{INTRODUCTION}

Bengkulu Province is one of the provinces in the western part of the island of Sumatra at latitude 2016'3031 LS and longitude 10101'103041 'BT. Bengkulu Province is a mountainous area of Bukit Barisan and extends from the border of West Sumatra Province to the border of Lampung Province along approximately $567 \mathrm{~km}$ with an area of $151.70 \mathrm{~km} 2$, located on the west coast of Sumatra Island with a coastal area of around $525 \mathrm{~km}$ (Bappeda, 2016). Bengkulu Province has several small islands, one of which is Tikus Island, which is the only island in the city of Bengkulu. Tikus Island is surrounded by a vast expanse of coral reef so that it can protect this island from abrasion due to large waves. Damage to coral reefs has had a negative impact on Tikus Island, this can be seen with the decreasing area of Tikus Island due to abrasion which has progressed faster from year to year. Beach erosion is one of the serious problems that cause changes in coastline. In addition to natural processes, such as wind, currents and waves, human activities also cause coastal erosion (Bakhtiar, 2013). Tikus Island is a small coral island that is about $0.8 \mathrm{Ha}$ in the west of Bengkulu City. with a distance of about $10 \mathrm{KM}$ from the city center, Tikus Island is surrounded by coral and is rich in biological resources and has been designated as a tourist forest with Minister of Forestry Decree No. 602 / Kpts-II / 1991. Tikus Island has maritime ecotourism potential The potential of fauna in the form of coral reef ecosystems and marine biota with clear and clean waters and not too deep, and various types of beautiful ornamental fish, besides that in the sea area there are safe locations for basic diving activities the sea, with its clear water and beautiful coral stone, so it is very suitable for diving and snorkeling, this is a special attraction for visitors and an attractive marine tourism destination. The condition of the white sand at night becomes the habitat of hawksbill

* Corresponding author. Email address: herlin_olin81@yahoo.com 
turtles. Under the waters around Tikus Island there is a beautiful natural panorama of the sea, and is very suitable for tourists who enjoy diving. Other than that. To get to Tikus Island tourism object, it can be reached for 30 minutes from Tapak Padri Beach, Bengkulu City by using a fishing boat, as well as providing local boats for rent are also ready to be a guide for tourists visiting Tikus Island. The purpose of this study was to find out how the strategy of developing Tikus island of Bengkulu province tourism. Fahmi (2016) defines SWOT is the identification of strengths and weaknesses internally and externally from an opportunity and threat that will come from the environment around the business

Tikus Island has a selling value in terms of tourism and a variety of economic potential that can be developed to increase PAD Regional Original Income) Bengkulu Provincial Government, this is in line with the Bengkulu Provincial government program to make Bengkulu Province as a Province of International Tourism destinations, development of tourism sector is a program The superior of Tikus Island Government which is one of the natural tourism islands in Bengkulu Province has its own advantages in addition to having superiority and selling value from its natural conditions also has a unique and distinctive name which gives a special attraction for tourists. However, from the many tourist advantages possessed by the Tikus Island, there are not many known tourists, and have not been exploited by the Bengkulu Province government so that it has not contributed to the Bengkulu Province PAD and lack of facilities that can support the Pariwisa sector in Tikus Island.Tourism development to Tikus Island. One of the biggest contributors to increasing Regional Original Income (PAD) is the tourism sector. So that the need for a tourism development strategy is one of the strategic agendas in increasing the economy and Regional Revenue (PAD) of Bengkulu Province. In an effort to support the Government's Program Towards Bengkulu Province of tourism through the development and development of tourism potential on the Tikus Island.

\section{LITERATURE REVIEW}

\section{Tourism}

In ethomology tourism comes the word "tourism" means the Main journey (Utama, 2016).Tourism is closely related to social, political, economic, security, order, hospitality, culture, health issues, including various social institutions that regulate it (Pitana and Gayatri, 2005 p. 34). Tourism is the whole activity of the Government, the business world and the community to organizing, manage and service the needs of tourists in Sakukani (Sakukani 2003). Tourism according to A.J. Norval in Muljadi and Siti Nurhayati (2012) are all activities related to the entry, residence, and movement of foreign populations within or outside a particular country, city, or region. According to the broader definition put forward by H. Kodhyat (2003) tourism is a trip from one place to another in the temporary, carried out by individuals or groups, as an effort to find balance and happiness with the environment in the dimensions of social, cultural, natural , and science. Furthermore, according to (Musanef, 2005) defines tourism as a journey that is carried out for a while, which is carried out from one place to another to enjoy trips for sightseeing and recreation.Tourism has the role of empowering scarce resources and making the tourism industry sustainable and life cycle (Theobald, 2004 in Main, 2016).

Yoeti (2008) tourism must meet the four criteria below, namely:

a. The trip is carried out from one place to another, the trip is done outside the residence where the person usually lives.

b. The purpose of the trip is done solely for fun, without copying in the country, city or DTW visited.

c. The money spent by tourists is brought from their home countries, where they can live or stay, and not be obtained because of the results of the business during the tour. 


\section{DEVELOPMENT STRATEGY TOURISM TIKUS ISLAND BENGKULU PROVINCE WITH SWOT ANALYSIS}

d. Travel is carried out at least 24 hours or more. In terms of tourism there are four factors that must be within the limits of a definition of tourism. These factors are that the trip is carried out from one place to another, the trip must be associated with people who travel only as visitors to the tourist attractions.

Development Strategy Tourism

Suryono (2004) the strategy in principle is related to the problem: policy, determining the objectives to be achieved and determining the ways or methods of using facilities and infrastructure. Hasan (2015). Strategy is an integrated and coordinated action designed to exploit all existing capabilities to gain competitive advantage in order to achieve goals (Reksohadiprodjo, 2000). Rivew's strategy must be able to provide a useful picture of the prospects and market share of tourists towards tourist attractions and who (segments) might be interested in the product.

The main elements that must receive attention in order to support the development of tourism in tourist destinations involving planning, implementation of development and tourism development (Suwantoro, 2004), covering 5 (five) elements :

a. Tourist attractions and attractions Attraction is a potential that drives the presence of tourists to a tourist destination.

b. Tourist infrastructure Tourism infrastructure is natural resources and man-made resources that are absolutely needed by tourists in their travels in tourist destinations, such as roads, electricity, water, telecommunications, terminals, bridges and so forth.

c. Tourist facilities Tourist facilities are a complete tourist destination that is needed to serve the needs of tourists in enjoying their sightseeing trips.

d. Management / infrastructure Infrastructure is a situation supporting the function of tourism facilities and infrastructure, both in the form of regulatory systems and physical buildings above the ground and underground.

e. Community / environment Communities in tourist areas need to understand the various types and quality of services needed by tourists. The environment around tourism objects needs to be considered carefully so as not to be damaged and polluted.

Yoeti (2008) development is a business or a way to advance and develop something that already exists. Tourism development in a tourist destination will always be taken into account with the benefits and benefits for the community around it. In carrying out its functions and roles in regional tourism development, regional governments must make various efforts in developing tourism facilities and infrastructure. Suryadana and Oktavia (2015) components of tourism development can be grouped as follows:
a. Anthrax and tourist activities
b. Accommodation
c. Tourist facilities and services
d. Transportation facilities and services
e. Other infrastructure
f. Institutional element

\section{Marine Tourism}

Marine Tourism is often interpreted as activities such as: Diving, Snorkeling, Fishing, Surfing, Sunbathing, watching Sunset and Sunrise. But maritime tourism is not only limited to the activities mentioned above but also activities that are more about adding knowledge, especially knowledge of the sea and how to live by relying on the results of the sea and much more. More importantly, to go to a maritime tourist spot, one must take the sea route by ship. Sumantoro (2004 h.17) defines marine tours, namely a visit to a tourist attraction, especially to witness the beauty of the ocean, diving ( wreck-diving) with complete diving equipment. In Indonesia there are many areas that have the potential for marine tourism, namely the Thousand Islands in Jakarta Bay, Toba Lake, Bali Island Beach and the surrounding small islands and many other marine tourism in each of the provinces Indonesia. 
SWOT Analysis

SWOT stands for Strength (S), Weaknesses (W), Opportunities (O) and Threats (T). Fahmi (2016) defines SWOT is the identification of strengths and weaknesses internally and externally from an opportunity and threat that will come from the environment around the business. SWOT benefits the development of strategies because it can find the elements of weakness and strength that are owned, so that it can formulate a strategy that is good at achieving the expected goals.

Regional Original Income

Utama (2016) explains that the impact of tourism on the economy is exchange of foreign exchange, government revenues, employment, infrastructure development and improving the economy of the community. According to law number 33 of 2004 concerning Financial Balance Central Government and the Regional Government, it is intended that the source of Regional Original Revenue consists of:

a. Local tax

b. Regional Retribution

c. Separate results of regional wealth management

d. Other legitimate PAD.

In accordance with the explanation above that the source of regional income is part of voluntary contributions from all producers such as regional taxes, regional levies, the results of separated regional wealth management and other legitimate Regional Original Income is all revenues received by the region from sources within its own domain which are collected based on regional regulations in accordance with the prevailing laws and regulations (Halim, 2004).

Tourism sector is one of the sectors that plays an important role in increasing PAD and can finance Government activities and regional development, so the need for the Tikus Island tourism development strategy of Bengkulu province is part of Regional Original Revenue.

\section{RESEARCH METHOD}

The type of this research is descriptive exploratory research through data collection related to Tikus Island tourism development strategy. Data retrieval used in this study consists of primary data and secondary data. Obtaining primary data is done through questionnaires. The population in this research were all visitors, community providers of transportation facilities to the Tikus Island and the Bengkulu province, which amounted to 125 people or visitor who come to Tikus Island Bengkulu.

Table 1 Number of Respondents

\begin{tabular}{|c|c|c|c|}
\hline No & Respondents & $\begin{array}{l}\text { Population } \\
\text { (people) }\end{array}$ & $\begin{array}{l}\text { Sampel } \\
\text { (people) }\end{array}$ \\
\hline \multicolumn{4}{|c|}{ Respondents Internal } \\
\hline 1. & Head of service and employess Dinas & 15 & 1 \\
\hline 2 & Society and Service provider transportation & 10 & 1 \\
\hline \multicolumn{4}{|c|}{ Respondents Exstenal } \\
\hline 1 & Visitor & 100 & 1 \\
\hline & Total & 125 & 1 \\
\hline
\end{tabular}

To get the data needed, the data collection method used is:

a. Primary data, namely data collected directly from the research object selected as a sample.

b. Observation, Conducting direct observation and systematic recording of symptoms that appear on the object of research. 


\section{DEVELOPMENT STRATEGY TOURISM TIKUS ISLAND BENGKULU PROVINCE WITH SWOT ANALYSIS}

c. Questionnaire, Data collection is done by using questions that have been prepared by previous researchers. The questionnaire assessment uses a Likert scale (Sugiyono, 2010), with the following provisions:

1. Strongly agree (score 5)

2. Agree (score 4)

3. Doubt (score 3)

4. Disagree (score 2)

5. Strongly disagree (score 1)

d. Secondary data, data obtained from the Bengkulu Province Tourism Service.

\section{Analysis Methods SWOT analysis}

The SWOT analysis method where $\mathrm{S}$ is Strengt means strength, W is weakness means weakness, $\mathrm{O}$ is Opportunity means opportunity and $\mathrm{T}$ is Threats means threat. The data obtained will be assessed based on respondents' perceptions and analyzed descriptively by analyzing strengths, weaknesses, opportunities, and threats (SWOT analysis) as the basis for determining the development of Tikus Island tourism development strategy.To find out the state of the environment by analyzing internal strengths and weaknesses, opportunities and external threats are needed to collect data that can be divided into two external data and internal data. According to Fahmi (2013 p. 262) to form a representative SWOT formula by compiling and calculating weight values, rating and scores for external and internal tables.

SWOT analysis is determined by a combination of internal and external factors. SWOT analysis uses a SWOT matrix that can clearly illustrate how the external opportunities and threats faced by rat island visitors can be adjusted to their strengths and weaknesses.

1. Internal Factor Analysis (IFAS)

The IFE matrix is used to determine the internal factors of a weak strategy that are considered important. According to Rangkuti (2015 p.262) The work stages of the IFE matrix are as follows :

a. Determine the factors that are the strengths and weaknesses of the development of Tikus Island tourism.

b. Give the weight of each of these factors a scale ranging from 1.0 (most important) to 0.0 (not important), based on the influence of these factors on the strategic position of the development of Tikus Island tourism. (All of these weights cannot exceed the total score of 1.00).

c. Calculate the rating for each factor by scaling from 4 (Outstanding) to 1 (Poor), based on the influence of these factors on the development strategy of Tikus Island tourism.

d. Multiply the weights by rating to get the weighting factor. The result is a weighting score for each factor whose value varies from 4.0 (Outstanding) to 1.0 (Poor).

e. Add up the weighting score, to get the total weighting score for the variable concerned. This total value shows how the condition of rat island tourism reacts to its internal strategic factors.

2. External Factor Analysis (EFAS)

Evaluate external factors the EFAS matrix is used, which is used to find out the external factors related to opportunities and threats, with the following stages of work:

a. Determine the factors that become opportunities and threats to the development of the island rat tourism.

b. Give the weight of each of these factors a scale ranging from 1.0 (most important) to 0.0 (not important), based on the influence of these factors on the strategic position of increasing the income of the fishing community. (All of these weights must not exceed the total score of 1.00). Calculate the rating for 
each factor by scaling from 4 (Outstanding) to 1 (Poor), based on the effect of these factors on the development of Tikus Island tourism.

c. Multiply the weights by rating to get the weighting factor. The result is a weighting score for each of the factors whose values vary from 4.0 (Outstanding) to 1.0 (Poor).

d. Add up the weighting score, to get the total weighting score for the respondent concerned. This total value shows how rodent island visitors react to external strategic factors.

SWOT analysis is determined by a combination of internal and external factors. The SWOT analysis uses a SWOT matrix that can clearly illustrate how external opportunities and threats faced by visitors to the rat island can be adjusted to their strengths and weaknesses.

Table 2 SWOT Matrix

\begin{tabular}{cll}
\hline \multicolumn{1}{c}{ IFAS } & \multicolumn{1}{c}{ Strenght } & \multicolumn{1}{c}{ Weaknesses } \\
EFAS & Strategy S-O create strategies & $\begin{array}{l}\text { Strategy W-O create strategy for } \\
\text { minimize weaknesses }\end{array}$ \\
Thing Strength & $\begin{array}{l}\text { Strategy W-T create strategy for } \\
\text { minimize weaknesses resolve } \\
\text { threats }\end{array}$ \\
\hline
\end{tabular}

Explanation :

a. S-O strategy is used to utilize all existing strengths and to make the best use of all opportunities.

b. S-T strategy is a strategy to use the power to overcome threats and minimize weaknesses

c. W-O Strategy is a Strategy used to take advantage of existing opportunities by minimizing weaknesses.

d. W-T Strategy is this strategy based on defensive activities and seeks to minimize existing weaknesses and avoid threats.

The following development strategies are carried out by looking at external factors and which internal factors can be best utilized and what threats to avoid and weaknesses that must be minimized can be seen in the following explanation of the SWOT quadrant (Rangkuti, 2016) :

a. Quadrant 1 is a very favorable situation for managers, namely the Bengkulu Province Tourism Service, because it has the opportunity and strength that exists.

b. Quadrant 2 is despite facing various threats, the manager (Bengkulu Province Tourism Office) still has the power to take advantage of long-term opportunities.

c. Quadrant 3, namely the manager (Bengkulu Province Tourism Office) faces a huge market opportunity, but on the other hand there are several internal weaknesses.

d. Quadrant 4, this position is the most unprofitable, where the manager (Bengkulu Provincial Tourism Office) faces various threats. 


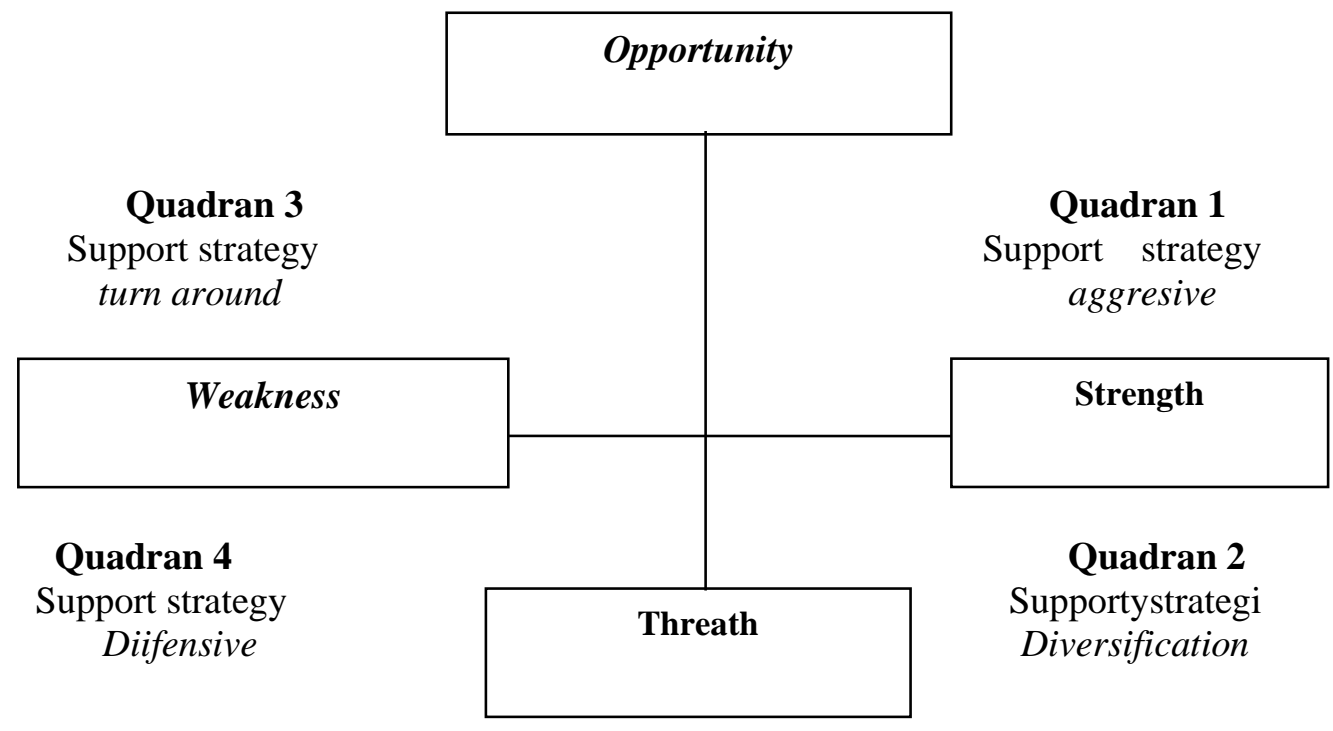

Figure 1 SWOT Analysis Diagram

In the diagram above shows that the meeting point between strengths, weaknesses, opportunities and threats is quadrant I, which means that the strategy applied is to support aggressive strategy. In this quadrant I shows that the rat island tourism object of Bengkulu province has the same opportunity (Opportunity) and Weakness (Weakness) so that the strategy that can be applied is supporting aggressive policy (Growth Oriented Strategy).

\section{RESULT RESEARCH AND DISCUSSION}

Initially this Tikus Island was a place for fishermen to stop when they were looking for fish. Tikus Island is a small island located in the west of Bengkulu City, $10 \mathrm{~km}$ from the center of Bengkulu City, which is directly connected to the Indian Ocean, geographically located at the coordinate point 3050'17.55 "LS and 102010'50,59" BT which have an area of 2 ha at first, and now the area of rat islands is only 0.6 ha which is supported by 200 ha of coral reefs. To go to the rat island can be obtained through the fishing village of Sepang Bay, Jakat Beach and the port of Bengkulu, Bengkulu, which can be taken approximately 1.5 hours Tikus Island is located in Teluk Segara District, Marlborough.

\section{Internal Factor Analysis (IFAS)}

Internal factor SWOT analysis (IFAS). Obtained internal strategic factors consisting of Strength (S) and Weakness (W) obtained a total score of 4.28, so it can be concluded that the attraction of Bengkulu Tikus Island has Strength (S) of 2.27 which is greater than Weakness (W) of 2.01 .

\section{Strength}

a. People know the attraction of the Tikus Island

The Tikus Island attraction is the only nearest island in Bengkulu Province and the distance covered is very affordable, which is less than 1 hour.

b. Small island with coral and a variety of amazing biological resources

The beauty of the Tikus Island consisting of attractive corals and marine life with various types that are not found in other tourist attractions in the province of Bengkulu.

c. Unspoiled marine tourism 
Sea conditions on the island of rats that have not been polluted and are still natural have a special attraction.

d. Have an interesting view

The beauty offered on the Tikus Island, natural conditions that are still beautiful and beautiful underwater tours.

e. Hit destination in the city of Bengkulu

Tikus Island, which offers its own beauty, where tourists can do snrokling and diving while traveling there which is not obtained in other tourist sites in Bengkulu province, has become a rat island, a tourist destination that is starting to be visited.

\section{Weaknesess}

a. Lack of promotion,

So far, the information of the Tikus Island attraction is only known from the closest people and social media.

b. Transportation is still limited

For trips to the island of rats, visitors must use sea transportation (ships), only so far sea transportation is still few that are provided by service providers.

c. No lodging available on site

Tikus Island tourist attractions, do not yet provide lodging places for tourists who want to spend the night in the island of mice, so tourists visiting the island of mice have to go home today when they want to travel to the island of mice

d. Located far from the city center,

To visit the Tikus Island tourist attractions, visitors must travel 45 minutes from the city of Bengkulu.

e. Depends on weather conditions

Uncertain weather conditions make tourist trips to the island of mice disrupted, because the means of transportation used cannot deliver visitors to the island of mice. Besides that, if the weather conditions are not good, the visitors who are already on the island of rats cannot snorkel and dive in the attractions of the Tikus Island.

\section{External Factor Analysis (EFAS)}

While the results of the SWOT analysis of external factors (EFAS), which consists of Opportunities $(\mathrm{O})$ and Threats $(\mathrm{T})$ with a total score of 4.25, so it can be concluded that the Bengkulu Tikus Island has an Opportunity (O) of 2.32 more the amount of Threat $(\mathrm{T})$ is 1.93 .

\section{Opportunity}

a. Can be used as a challenging marine tourism

The attraction of the Tikus Island is an interesting marine tourism destination that allows visitors to enjoy the underwater beauty that is very interesting.

b. Pendapatan Asli Daerah (PAD) More and more visitors

Who travel to the Tikus Island, will indirectly have a positive impact on the community and the Government.

c. Can be used as Bengkulu tourism icon

Travel to the Tikus Island is the only marine tourism in the province of Bengkulu, so that if managed properly will become a very interesting tourist icon.

d. Can attract tourism interest with its natural beauty

The natural beauty offered by the attraction of the Tikus Island, can attract tourism both from within the city of Bengkulu or from outside the city of Bengkulu.

e. On the Tikus Island can interact with marine life through snorkeling. Interacting with marine life via snorkeling, one of the flag ship offered on the Tikus Island attraction that is not in the attractions in Bengkulu province

f. 


\section{DEVELOPMENT STRATEGY TOURISM TIKUS ISLAND BENGKULU PROVINCE WITH SWOT ANALYSIS}

\section{Threats}

a. The occurrence of abrasion

The occurrence of abrasion or erosion process by waves on the rat island will damage the beauty of the rat island region, namely the shrinking of the beach area. The occurrence of erosion by sea waves if not immediately addressed will threaten the existence of Tikus Islands which will be lost hit by the waves, because the land area will become a part that is inundated with water.

b. The existence of animal habitats from the threat of extinction

If not treated immediately, due to abrasion will threaten the habitat of animals on the rat island threatened with extinction, because of the damage to the reefs due to the pounding waves.

c. Management of Tikus Island is inadequate

Nadequate management of the Tikus Island has made the lack of visitor interest, such as the lack of facilities and infrastructure for visitors who travel to the island of mice.

d. Other tourist attractions in the city of Bengkulu easily accessible

The number of other tourist attractions in the city of Bengkulu that are easily reached makes visitors prefer less interested in the island of mice.

e. Reduction in the physical quality of the natural environment and the attractiveness of the Tikus Island

If it is not managed properly and there is no prevention due to abrasion in the Tikus Iland attraction, it will result in a decrease in the physical quality of the natural environment and the attractiveness of the rat island, which will make visitors less interested in traveling to the Tikus Island.

IFAS and EFAS SWOT analysis, following the results of recapitulation scores related to Strength $(\mathrm{S})$, Weaknesses $(\mathrm{W})$, Opportunities $(\mathrm{O})$ and Threats $(\mathrm{T})$ :

Table 4. Recapitulation IFAS and EFAS

\begin{tabular}{ccccc} 
& \multicolumn{2}{c}{ IFAS } & \multicolumn{2}{c}{ EFAS } \\
& $S$ & $W$ & $O$ & $T$ \\
\hline Development & 2,2 & 2,01 & 2,32 & 1,93 \\
Strategy & 7 & & \\
Quadran & $2,27-2,01=$ & $2,32-1,93=0,39$ \\
& 0,26 & & \\
\hline
\end{tabular}

The results of IFAS and EFAS calculations in table 2 above show that the meeting point between Strengths, Weaknesses, Opportunities and Threats is quadrant I, which means that the strategy applied is to support aggressive strategy. In this quadrant I shows that the Tikus Island tourism object of Bengkulu province has equal Opportunities (O) and Weakness (W) so that the strategy that can be applied is to support aggressive wisdom (Growth Oriented Strategy).

a. Development Strategy Tourism Tikus Island Bengkulu Province

The strategy for developing Bengkulu Tikus Island attractions has a greater Opportunity to development, namely:

1) Development of transportation and supporting facilities to the Tikus Island tourist area

2) Development of facilities and infrastructure such as structuring the area of Tikus Island tourist attraction.

3) Organizing tourism events organized by the Regional Government in the Tikus island tourist area.

4) The existence of community participation in tourism awareness

5) The existence of tourism business actors 
Based on the results of the analysis that have been carried out on the Tourism Development strategy of the Tikus Island of Bengkulu Province in increasing the Regional Original Revenue that need to be raised are :

1) Making Tikus Island tourist attraction as a superior area for marine tourism destinations that will potentially be developed, with consideration of multiflyer economic effects that aim to improve the welfare of the community.

2) Development of various other supporting facilities such as lodging.

3) Making a tourist attraction for Tikus Islands is one of the icons of marine tourism in Bengkulu Province,.

4) Improve partnership relationships between institutions in the management of Tikus Island attractions. Collaboration between the management of Tikus Island attractions by the private sector and optimal government parties has its contribution to Regional Original Income.

5) Support for tourism supporting infrastructure.

6) The existence of regulation and development of tourism human resources.

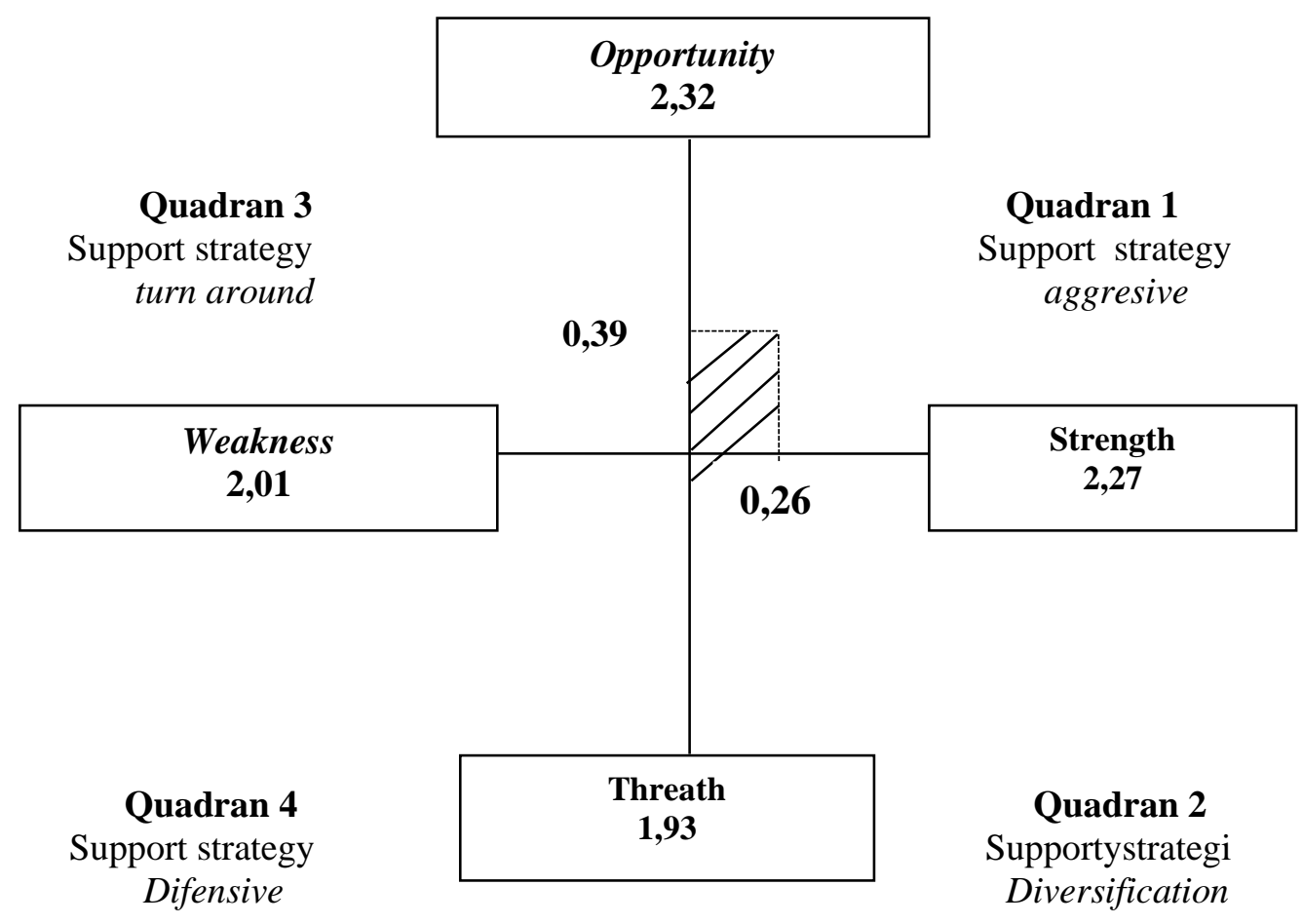

Figure 2 SWOT Analysis Diagram

In the diagram above shows that the meeting point between Strengths, Weaknesses, Opportunities and Threats is quadrant I, which means that the strategy applied is to support aggressive strategy. In this quadrant I shows that the Tikus Island tourism object of Bengkulu province has the same opportunity (Opportunity) and Weakness (Weakness) so that the strategy that can be applied is supporting aggressive policy (Growth Oriented Strategy).

\section{CONCLUSION}

SWOT analysis of internal factors (IFAS) consisting of Strength (S) and Weakness (W) obtained a total score of 4.28, so it can be concluded that the attraction of Bengkulu Tikus Island has Strength of 2.27 which is greater than weakness of 2.01. While external factors (EFAS), which consist of opportunities $(\mathrm{O})$ and Threats $(\mathrm{T})$ with a total 


\section{DEVELOPMENT STRATEGY TOURISM TIKUS ISLAND BENGKULU PROVINCE WITH SWOT ANALYSIS}

score of 4.25, so it can be concluded that the Bengkulu Tikus Island has an Opportunity (O) of 2.32 which is greater than the threat (Treaths) of 1.93.

The SWOT diagram shows that the meeting point between strengths, weaknesses, opportunities and threats is in quadrant I, which means that the strategy applied is to support aggressive strategy. In quadrant I this shows that tourism objects in the Tikus Island of Bengkulu province have equal Opportunities (O) and Weakness (W) so that the strategy that can be applied is to support aggressive policy (Growth Oriented Strategy), namely by developing transportation and supporting facilities to rat island tourist area. The selection of the right strategy in developing Tikus Island tourism in Bengkulu province will have an impact on Regional Original Revenue (PAD) such as increasing numbers of tourists, accommodation facilities and tourist shopping places, with many tourists coming to the Tikus Island increasing restaurant tax, kiosk retribution and the presence of entrance ticket service for tourists who will visit Tikus Island attractions.

\section{References}

Fahmi, I. (2013). Manajemen Risiko. Bandung: Alfabeta

Fahmi, I. (2015). Manajemen Strategis Teori dan Aplikasi. Bandung:Alfabeta

Ghozali, I. (2005). Aplikasi Analisis Multivariate dengan Program SPSS. Edisi Ketiga. Semarang: Badan Penerbit Universitas Diponegoro.

Hasan, A. (2015). Tourism Marketing. Jakarta: Centre for academic publishing service.

Halim, A. (2004). Akuntansi Keuangan Daerah. Salemba Empat. Jakarta.

Nurhadi, F. D. C., Mardiyono., \& Rengu, S. P. (2014). Strategi Pengembangan Pariwisata Oleh Pemerintah Daerah Terhadap Pendapatan Asli Daerah (Studi pada Dinas Pemuda, Olahraga, Kebudayaan dan Pariwisata Kabupaten Mojokero). Jurnal Administrasi Publik (JAP), 2(2), 325-331.

Pitana, I. G., Gayatri, P. (2005). Sosiologi Pariwsata. Yogyakarta : Andi

Rangkuti, F. (2015). Teknik Membedah Kasus Bisnis Analisis SWOT. Jakarta : Gramedia

Reksohadiprodjo, S. (2000). Manajemen Strategi. Yogyakarta.BPFE

Ridjal D. S. (1997). Peluang Pariwisata Mutiara Sumber Widya, Benih Kecerdasan.

Soebagyo. (2013). Strategi Pengembangan Pariwisata Indonesia. Jurnal Liquidity, $1(2), 153-158$

Soekardijo, R. G. (1997). Anatomi Pariwisata (memahami Pariwisata Sebagai "systemic Lingkage). Jakarta: Gramedia Pustaka Utama.

Suryadana, L., \& Vanny, O. (2015). Pengantar Pemasaran Pariwisata. Bandung: alfabeta.

Suwantoro, G. (2004). Dasar-dasar Pariwisata. Yogyakarta : Andi

Utama, R. B. (2016). Pemasaran Pariwisata. Yogyakarta: Andi

Yaukani, H. R. (2003). Pesona Pariwisata Indonesia. Jakarta: Nuansa Madani

Yoeti, O. A. (1994). Pengantar Ilmu Pariwisata. Bandung : Angkasa. 
Dinas Pariwisata Provinsi Bengkulu. Bengkulu Province Tourism Booklet Edition 01

Kementerian Kebudayaan dan Pariwisata Republik Indonesia. Informasi Pariwisata Nusantara 